\title{
The Level of Organizational Commitment Among School Teachers in the Arab Israeli Schools from Their Point of View
}

\author{
Fathi shamma- Israel \\ Department, Administration Management, Education Faculty, Yarmouk \\ University, Irbid, Jordan
}

Doi: 10.19044/ejes.v5no2a8

URL:http://dx.doi.org/10.19044/ejes.v5no2a8

\begin{abstract}
The current study aimed to reveal the Level of the organizational commitment among the teachers in the Arab Israeli schools. The study sample consisted of (230) male and female teachers, to achieve the objectives of the study, the researcher used the analytical, descriptive approach where he prepared a questionnaire as a tool for data collection from the members of the study sample. After conducting the appropriate statistical methods, the researcher in this study concluded the following results: there is a very great degree in the level of the organizational commitment among the teachers in the Arab Israeli schools, The results also indicate that the teachers who belong to their schools are very committed, According to the results, the study recommended the need to maintain and strengthen this degree through continuing and preserving this status and conducting studies on the organizational commitment and its relationship to other demographic variables, such as the educational level, the educational stage, and the type of school.
\end{abstract}

Keywords: Organizational commitment, Arab Israeli schools, Teachers.

\section{Introduction}

Organizational commitment is one of the most important indicators of human behavior that is characterized by complexity, which includes all processes as well as intellectual, motor, emotional and social activities, where individuals do to compliment and adapt The school is considered as one of the most important educational organizations that aim at educating human beings and helping them to develop and expand all aspects of their personality (mental, physical, psychological, spiritual and social), according to their ability, readiness, tendencies and trends, with this growth directed at the right social destination. In order for the school to function properly, physical and 
human resources are needed[1] (Rashidi, 2010).the environment he lives in, satisfy his needs, and solve his problems.[2]

Harris (2009) defined the organizational commitment as the process of linking employees in the organization, since they regard the commitment as a sense of loyalty and belonging to the institutions they work in by clarifying the value of work and integration into it. Through search in many researches related studies, a number of studies were found that dealt with the research variables represented in the organizational commitment and procedural justice. Some of these studies are as follows.

\subsection{Literature Review and Related studies}

Organizational commitment is defined as an important part of the employee's psychological condition. Individuals with a high level of commitment usually exhibit positive behaviors in the workplace, such as job satisfaction and organizational citizenship, which is of great benefit to the organization[3] (Albdour, Ikhlas \& Altarawneh, 2014: p3).

[4]Kean et al., (2017) conducted a study aimed at determining the relationship between the administrative practices of principals and the organizational commitment of teachers. The researchers used the descriptive expressive method. The study sample consisted of (340) secondary school teachers in Malaysia. The study found that there is a high degree of commitment among teachers in everything related to teaching and that there is a strong relationship between the practices of the principal and the commitment of teachers with regard to improving working conditions, including the educational climate and giving opportunities to participate in decision-making.

\subsection{Operational Definition of the Term: Organizational commitment}

Organizational commitment is an important element in achieving objectives, stability and innovation in institutions, which will increase the interest of researchers to study the subject of functional commitment and its impact on the behavior of individuals and factors affecting it. Many researchers agreed that organizational commitment emerges as a result of interaction between individuals' personalities and behaviors and their characteristics, as well as prevailing regulatory factors, labor pressure, the general environment, and societal indicators, (Harris, 2009).

\section{Methods}

\subsection{Research questions}

What is the level of organizational commitment of school teachers in the Arab Israeli schools from their point of view? 


\subsection{Study sample}

This study sample include (230) male and female teachers working in Israeli within Arab Schools, divided into three stages (Elementary, junior high school and high school).

\subsection{Study Tools}

To achieve the study goals, the researcher had developed a questionnaire from two parts, The first one related to the demographic changes, which include (gender, academic qualification).The second organizational commitment that included (18) items paragraphs.

\subsection{Methodology}

Descriptive Study Method was used in this study, To see the degree organizational commitment of the teachers from their point of view.

\section{5. study variables}

Dependent variables

Gender ( male /female).

Independent variables: The Degree of organizational commitment within Israeli Arab Schools.

\section{Discussion and Results}

The table shows that the female number was the higher with a percentage of $53.2 \%$, while the males were $47.8 \%$ from the study sample.

Table 1 : Distribution of the sample of the study according to the gender variable

\begin{tabular}{|c|c|c|c|c|}
\hline Variable & & 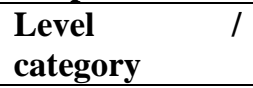 & Number & Percentage\% \\
\hline \multirow[t]{3}{*}{ Gender } & & Male & 110 & 47.8 \\
\hline & & female & 120 & 53.2 \\
\hline & \multicolumn{2}{|l|}{ Total } & 230 & 100.0 \\
\hline
\end{tabular}

What is the level of organizational commitment of the Arab Israeli school teachers from their point of view?

In order to answer this question, the mean, standard deviations and ranks were extracted from the study sample responses on the level of organizational commitment of school teachers in the Arab schools in Israel from their point of view, as follows: 
Table 2 : The means and standard deviations of the areas of the organizational commitment filed arranged in descending order by the means

\begin{tabular}{|c|c|c|c|c|c|}
\hline No & Rank & Paragraphs & Mean & $\begin{array}{l}\text { Standard } \\
\text { deviation }\end{array}$ & Level \\
\hline 4 & 1 & $\begin{array}{l}\text { The reputation of the school } \\
\text { concerns me }\end{array}$ & 4.72 & .572 & Very high \\
\hline 6 & 2 & Always attend school. & 4.58 & .666 & Very high \\
\hline 18 & 3 & $\begin{array}{l}\text { Management relationship is } \\
\text { built on mutual respect }\end{array}$ & 4.46 & .786 & Very high \\
\hline 7 & 4 & $\begin{array}{l}\text { I prefer the public interest over } \\
\text { the personal interest. }\end{array}$ & 4.41 & .756 & Very high \\
\hline 8 & 5 & $\begin{array}{l}\text { I am proud to be attending this } \\
\text { school }\end{array}$ & 4.41 & .792 & Very high \\
\hline 14 & 6 & $\begin{array}{l}\text { I am ready to keep up with the } \\
\text { latest developments to achieve } \\
\text { the school's objectives. }\end{array}$ & 4.41 & .722 & Very high \\
\hline 10 & 7 & $\begin{array}{l}\text { I make a great effort to help the } \\
\text { school to achieve its goals }\end{array}$ & 4.40 & .724 & Very high \\
\hline 12 & 8 & $\begin{array}{l}\text { I am ready to do any task that } \\
\text { gave to me in the school }\end{array}$ & 4.40 & .712 & Very high \\
\hline 1 & 9 & $\begin{array}{l}\text { I encourage parents to register } \\
\text { their children in the school }\end{array}$ & 4.38 & .802 & Very high \\
\hline 2 & 10 & $\begin{array}{l}\text { I will participate in the school } \\
\text { activities }\end{array}$ & 4.38 & .755 & Very high \\
\hline 13 & 11 & $\begin{array}{l}\text { My school is an organization } \\
\text { that is good to work in }\end{array}$ & 4.38 & .817 & Very high \\
\hline 16 & 12 & I invest my time effectively. & 4.33 & .723 & Very high \\
\hline 9 & 13 & $\begin{array}{l}\text { I am following up the } \\
\text { administrative } \\
\text { organizational affairs of the } \\
\text { school }\end{array}$ & 4.27 & .834 & Very high \\
\hline 3 & 14 & $\begin{array}{l}\text { The school motivates me to } \\
\text { provide the best performance. }\end{array}$ & 4.23 & .848 & Very high \\
\hline 17 & 15 & $\begin{array}{l}\text { I have the willing to stay at my } \\
\text { school until I retire }\end{array}$ & 4.22 & .975 & Very high \\
\hline 11 & 16 & $\begin{array}{l}\text { I have the willing to work in the } \\
\text { school outside the working } \\
\text { hours }\end{array}$ & 4.02 & .975 & High \\
\hline 15 & 17 & $\begin{array}{l}\text { The justice organizational } \\
\text { climate in the school makes } \\
\text { teachers committed to their } \\
\text { goals }\end{array}$ & 3.99 & 1.000 & High \\
\hline 5 & 18 & $\begin{array}{l}\text { If I has the chance to work in the } \\
\text { school after retire I will agree }\end{array}$ & 3.79 & 1.282 & High \\
\hline & & Organizational Commitment & 4.32 & .581 & High \\
\hline
\end{tabular}

This field includes (18) paragraphs, to identify the level of organizational commitment of the teachers in Arab schools in Israel. The sample members see that the level of organizational commitment was very 
high, and the total mean was (4.32), the means and standard deviations have been extracted for each paragraph of the field.

The table shows that the values of the means for this field ranged between (3.79-4.72), which is generally very high. Paragraph (4), which states (The reputation of the school concerns me) ranked first with a mean of (4.72) and a standard deviation of (.57), followed by the second paragraph, which states (Always attend school). With a mean of (4.58) and a standard deviation of (666).

The paragraph (5) that states "If I has the chance to work in the school after retire I will agree" was ranked last with a mean of (3.79) and a standard deviation of (1.282), which reflects the very high level of distributive justice.

This result is attributed to the teachers' belief in the decisions and actions taken in a fair and transparent manner. Thus, the employees succeed in performing the tasks entrusted to them in an effective and worthy manner. The male and female teachers also believe in the goals of their organization, and working hard to achieve the goals and vision. The previous result is existed in paragraph (10) that states, "I make a great effort to help the school to achieve its goals" with a mean of (4.40). Paragraph (16), which states (I invest my time effectively) has a mean of (4.33), the principals' awareness of the importance of the partnership, which creates a high spirit and morale among the teachers, and then increases the commitment and belonging of the teacher will increases his efforts regardless of the financial value achieved by the organization.

Through the results, it was noted that teachers are aware of the importance of maintaining their work as a source of livelihood; teachers are subjected to evaluation annually where the possibility of getting faire is existed. In the globalization context, the competition between schools has increased. One of the criteria that measure the quality of the school is the educational climate where the teachers are the most important part of it through their hard work to achieve the goals of the school and follow all the developments and innovations to give them to their students. This requires a degree of commitment. The fact that each renewal is introduced to the school requires additional work and training and rehabilitation courses.

This can be seen in paragraphs (14) that states, "I am ready to keep up with the latest developments to achieve the school's objectives" with a mean of (4.41), and paragraph (11) that states, "I have the willing to work in the school outside the working hours" with a mean of (4.02). In addition, paragraph (12) that states, "I am ready to do any task that gave to me in the school" had the same idea with a mean of (4.40).

The researcher believes that the relationship between principals and teachers is based on mutual respect, which is clearly reflected in the high degree of commitment of teachers [6] (Jiang, et. al., 2016). This is stated in 
paragraph (18) that states, "Management relationship is built on mutual respect" with a mean of (4.46). Building social relationships between teachers and management strengthens cohesion, understanding, enhances the spirit of teamwork, reduces negative competition among teachers and highlights efforts among individuals in the interest of the organization and its objectives. This can be seen in paragraph (7) that states, "I prefer the public interest over the personal interest" with a mean of (4.42).

Paragraph (3) that states, "The school motivates me to provide the best performance" came with a mean of (4.23). This is due to the high efficiency of teachers, in addition to the internal control, self-commitment and maintenance of the job, as well as by the prevailing positive educational teaching, the procedures of transparent policy and their fairly implementation, regardless of the demographic variables.

This stands out in both paragraph (1) that states, "I encourage parents to register their children in the school" with a mean of (4.38) and paragraph (4) that states, " The reputation of the school concerns me" with a mean of (4.72) a high degree of organizational commitment that is due to the job security.

This is attributed to the clear policy in the Ministry of Education that the funding of the school and the granting of the hours of the owners are in accordance with the number of students in the school and the reputation of the school, which encourage parents to register their children in the school guarantees the teacher continuity in work or increase in the proportion of the job or promotion.[7] (Sirnivasan, et. al., 2016)..

It was noted that teachers are working intensively and seriously to ensure the superiority of their school in the educational and social fields to gain the confidence of the people on one hand and to win the respect of the principal on the other. The result of the study in this question was consistent with the studies of Kean et al., (2017), [8] Ari et al. (2017), [9] Mousa \& Ruth(2016), [10] Kadiresen, et.al.,(2015).

\section{Conclusion}

Commitment is one of the most important conditions to survive in the age of competition between schools, so teachers understood that and they should have high belonging and double their efforts to keep their school on the map. Organizational commitment leads to attitudes and behaviors that are beneficial for the employee and the Organization. Commitment of an employee is a bonus for the organization, The results indicate that the teachers who belong to their schools are very committed, and make all they can in order to achieve the school goals, and There is a very great degree in the level of the organizational commitment among the teachers in Arab Israeli schools in Israel. 


\section{References:}

Albdour, A. \& Altarawneh,. (2014). Employee Engagement and Organizational Commitment: Evidence from Jordan. International Journal of Business, 19(2), 192-212.

Al-Rashidi, S. (2010). Personal Attitudes of High School Principals in Hail Educational Region and Their Relation to Administrative Creativity from Their Point of View. Unpublished Master Thesis, Mutah University, Karak, Jordan.

Ari, A., Caglayan, H. (2017). Relationship between organizational justice perceptions and organizational commitment levels of school of physical education and sports academicians. Journal of education and training studies. 5(4), 240-251.

Harris, K. J., Harvey, P. and Kacmar, K. M. (2009). 'Do social stressors impact everyone equally? An examination of the moderating impact of core selfevaluations'. Journal of Business and Psychology, 24,153-64.

Jiang, Z., Gollan, P. J., \& Brooks, G. (2016). Relationships between organizational justice, organizational trust and organizational commitment: a cross-cultural study of China, South Korea and Australia. The International Journal of Human Resource Management, 1-32.

Kadiresan, V., Selamat, M., Selladurai, S., Ramendran, Ch., \& Mohamed, M. (2015). Performance appraisal and training and development of human resource management practices (HRM) on organizational commitment and turnover intention. Asian Social Science, 11(24), 162-176.

Kean, T. H., Kannan, S., Piaw, C. Y., (2017), The Effect of School Bureaucracy on the Relationship between Principals Leadership Practices and Teach Commitment in Malaysia Secondary schools Malaysian Online Journal of Educational Sciences, 5(1), 37-55.

Mousa, M., \& Alas, R. (2016). Cultural diversity and organizational commitment: A study on teachers of primary public schools in Menoufia (Egypt). International business research. 9(7), 154-163

Rashidi, (2010). Organizational Climate And Its Influence On Organizational Commitment, International business and economics research Journal, 9(2), 1-9.

Srinivasan, P., Selvi, K., (2016), Organizational Commitment of Higher Secondary School Teachers, American Journal of Educational Research , 4(5), 404-407 